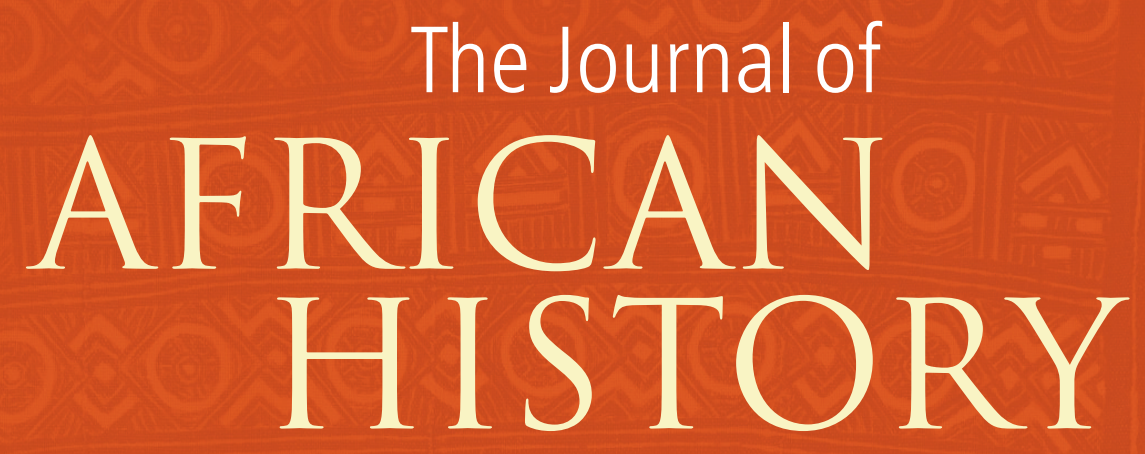

VOLUME $56 \cdot$ NUMBER $3 \cdot 2015$

CAMBRIDGE UNIVERSITY PRESS 


\section{AFRICAN HISTORY}

\author{
Editors \\ C. A. BABOU History Department, \\ University of Pennsylvania \\ K. BRECKENRIDGE WISER, University of the \\ Witwatersrand \\ B. COOPER Department of History, Rutgers, \\ The State University of New Jersey \\ R. REID Department of History, SOAS
}

\section{Reviews Editor}

Books for review should be sent to Professor Barbara Cooper, Department of History, Rutgers, The State University of New Jersey, 16 Seminary Place, Van Dyck Hall, New Brunswick, NJ 08901-1108, USA.bacooper@rci.rutgers.edu

\section{Founding Editors}

J. D. Fage University of Birmingham

R. A. Oliver SOAS

\section{Advisory Editorial Board}

E. K. Akyeampong Harvard University

M. Arnoldi Smithsonian Institution

D. Branch University of Warwick

A. Eckert Humboldt University

B. Fall University Cheik Anta Diop of Dakar

L. Fourchard University of Bordeaux

S. E. Greene Cornell University

J. Hyslop Colgate University

P. Lane Uppsala University

L. Lindsay University of North Carolina

G. E. Lydon University of California

G. Macola University of Kent

G. Mann Columbia University

H. Médard Université d'Aix-Marseille

M. Moorman Indiana University

N. Musisi University of Toronto

K. Mutongi Williams College

D. Newbury Smith College

A. Olukoju University of Lagos

S. Reese Northern Arizona University

D. Schoenbrun Northwestern University

L. M. Thomas University of Washington

L. White University of Florida

J. Willis Durham University

C C Cambridge University Press 2015

\section{SUBSCRIPTIONS}

The Journal of African History (ISSN $002 \mathrm{I}-8537$ ) is published three times a year. Three parts form a volume. The subscription price (excluding VAT) of volume 56, 2015 (which includes print and electronic access) is $£_{27 \mathrm{I}}$ (US $\$ 476$ in the USA, Canada and Mexico) for institutions; $£_{54}$ (US \$94 in the USA, Canada and Mexico) for individuals. Students ordering direct from the Press and certifying that the Journal is for their own personal use can subscribe to the print version at $£_{37}$ (US $\$ 59$ in the USA, Canada and Mexico). The electronic-only price available to institutional subscribers is $£_{23} 3$ (US $\$ 407$ in the USA, Canada and Mexico). Single parts $£_{9} 8$ net (US \$170 in the USA, Canada and Mexico). Prices include delivery by air where appropriate. EU subscribers (outside the UK) who are not registered for VAT should add VAT at their country's rate. VAT registered subscribers should provide their VAT registration number.

Orders, which must be accompanied by payment, may be sent to a bookseller or to the publisher: Cambridge University Press, Journals Fulfillment Department, UPH, Shaftesbury Road, Cambridge CB2 8BS, UK.; or in the USA, Canada and Mexico, to Cambridge University Press, Journals Fulfillment Department, Ioo Brook Hill Drive, West Nyack, New York I0994-2 I33. Japanese prices for institutions are available from Kinokuniya Company Ltd., PO Box 55, Chitose, Tokyo I 56, Japan.

Special arrangements exist for sponsoring individual subscriptions for African scholars, please apply to the publisher for details.

\section{COPYING}

This journal is registered with the Copyright Clearance Center, 222 Rosewood Drive, Danvers, MA I923. Organizations in the USA who are also registered with CCC may therefore copy material (beyond the limits permitted by sections 107 and 108 of US copyright law) subject to payment to CCC of the per-copy

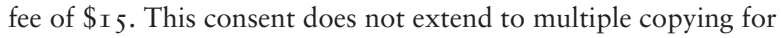
promotional or commercial purposes. Code $002 \mathrm{I}-8537 / 20 \mathrm{I} 5$ \$ I 5. ISI Tear Sheet Service, 350 I Market Street, Philadelphia, Pennsylvania I9I04, USA, is authorized to supply single copies of separate articles for private use only. Organizations authorized by the Copyright Licensing Agency may also copy material subject to the usual conditions.

For all other use, permission should be sought from Cambridge or the American Branch of Cambridge University Press.

Internet Access. This journal is included in the Cambridge Journals Online service which can be found at http://journals. cambridge.org/. For further information on other Press titles access http://www.cambridge.org/. 
The Journal of

\section{AFRICAN HISTORY}

\section{CONTENTS}

In Search of Precolonial Identity

'Lucumí', 'Terranova', and the Origins of the Yoruba Nation

Henry B. Lovejoy McMaster University

Olatunji Ojo Brock University, St Catharines

Children, Slavery, and the Colonial State

'I Want to Follow Kwaku': The Construction of Self and Home by Unfree Children in the Gold Coast, $c$. I94I

Jessica V. Cammaert Ryerson University

The Limits of Power over People in the Horn of Africa

'Stealing the Way' to Mecca: West African Pilgrims and Illicit Red Sea Passages, I920s-50s Jonathan Miran Western Washington University

The Unaccountable Census: Colonial Enumeration and its Implications for the Somali People of Kenya

Keren Weitzberg University of Pennsylvania

\section{Ideological Innovation in Postcolonial Africa}

Socialism on Safari: Wildlife and Nation-Building in Postcolonial Tanzania, I96I-77

Julie M. Weiskopf University of Wisconsin-La Crosse

Africanising Apartheid: Identity, Ideology, and State-Building in Post-Independence Africa

Jamie Miller Cornell University

\section{REVIEWS OF BOOKS}

Thomas Bierschenk and Jean-Pierre Olivier de Sardan (eds.), States at Work: Dynamics of African Bureaucracies.

\section{J. Tyler Dickovick}

Randy J. Sparks, Where the Negroes Are Masters: An African Port in the Era of the Slave Trade.

Toby Green 
ii $\operatorname{VOL} .56, \mathrm{NO} .3$

Kwasi Konadu, Transatlantic Africa I440-I 888 .

Jonathan Reynolds

Karlee Anne Sapoznik (ed.), The Letters and Other Writings of Gustavus Vassa (Olaudah 476 Equiano, the African): Documenting Abolition of the Slave Trade.

\section{Vanessa Mongey}

Toyin Falola (ed.), Esșù: Yoruba God, Power, and the Frontiers.

Susan A. C. Rosenfeld

Matthew M. Heaton, Black Skin, White Coats: Nigerian Psychiatrists, Decolonization, and 480 the Globalization of Psychiatry.

\section{Sally Swartz}

Abena Dove Osseo-Asare, Bitter Roots: The Search for Healing Plants in Africa.

\section{Laura M. Tilghman}

John Humphries, Search for the Nile's Source: The Ruined Reputation of John Petherick, 483 Nineteenth-Century Welsh Explorer.

\section{W. B. Carnochan}

Nathalie Carré, De la Côte aux confins: Récits de voyageurs swahili.

\section{Cecile Van Den Avenne}

Ousseina D. Alidou, Muslim Women in Postcolonial Kenya: Leadership, Representation, $\quad 487$ and Social Change.

\section{Hassan J. Ndzovu}

John Laband, Zulu Warriors: The Battle for the South African Frontier.

\section{Spencer Jones}

Todd Cleveland, Stones of Contention: A History of Africa's Diamonds.

\section{Candice Goucher}

Clifton Crais and Thomas V. McClendon (eds.), The South Africa Reader: History, Culture, Politics.

\section{Kenneth Wilburn}

Kwasi Konadu, The Akan People: A Documentary History.

\section{Emmanuel Ababio Ofosu-Mensah}

Elizabeth Wrangham, Ghana During the First World War: The Colonial Administration of Sir Hugh Clifford.

Roger S. Gocking 